\title{
How Discomfort Reproduces Settler Structures: Moving Beyond Fear and Becoming Imperfect Accomplices
}

\author{
Shawna M. Carroll ${ }^{1, *}$, Daniela Bascuñán ${ }^{2}$, Mark Sinke $^{2} \&$ Jean Paul Restoule ${ }^{3}$ \\ ${ }^{1}$ Graduate School of Education, Okayama University, Okayama, Japan \\ ${ }^{2}$ Ontario Institute for Studies in Education, University of Toronto, Toronto, Canada \\ ${ }^{3}$ Indigenous Education Department, University of Victoria, Victoria, Canada \\ *Correspondence: Graduate School of Education, Okayama University, Okayama, Japan. Tel: 81-090-6402-0033. \\ E-mail: scarroll@okayama-u.ac.jp
}

Received: January 23, 2020

Accepted: February 27, $2020 \quad$ Online Published: April 22, 2020

doi:10.5430/jct.v9n2p9

URL: https://doi.org/10.5430/jct.v9n2p9

\begin{abstract}
In this paper we explain how teachers can subvert settler colonial epistemology in their classrooms and become 'imperfect accomplices.' Drawing on a larger project, we focus on the ways non-Indigenous teachers understood their role in teaching Indigenous content and epistemologies through their lenses of 'fear,' which we re-theorize as 'anxiety.' These anxieties were enacted by the educators in two ways: stopping the teaching of Indigenous content and epistemologies, or using productive pausing for self-reflection. We explain how stopping the teaching outside of settler colonial epistemology is based on structures that impose fear to go outside of that epistemology. We then examine how some teachers pause within these structures of 'fear' and explain three strategies to become 'imperfect accomplices.'
\end{abstract}

Keywords: settler colonialism, perfect stranger, teacher education, anxieties, imperfect accomplice

\section{Introduction and Background}

We would like to begin this paper by acknowledging that we conducted this work on the territory of the Huron-Wendat and Petun First Nations, the Seneca, and the Mississaugas of the New Credit First Nations. This land has a long history of being a meeting ground of many Indigenous nations and is subject to the Dish With One Spoon Wampum Belt Covenant. We start with this acknowledgement to call attention to our shared responsibilities on this land to live in ways that adhere to the Dish With One Spoon Wampum Belt Covenant. Recognizing these relationships is at the root of our research. It is also representative of the ways that we continue to turn towards anticolonial action in our own practice by continually engaging with the shifting nature of the language and politics around land acknowledgements. Instead of claiming a position of being perfect strangers for "fear of offending," as explained by Susan Dion (2007, p. 331), we aim to be what we call imperfect accomplices (Carroll, 2019). Though anxieties or 'fears' may often get in the way of doing teaching work in a good way that promotes anticolonial relationships, we instead encourage educators to take steps in turning towards this work in order to continue becoming imperfect accomplices.

In this paper, we draw on data from a research study that examined the ways educators in Ontario incorporated Indigenous content and epistemologies into their classrooms. We explain the ways non-Indigenous teachers understand their role in teaching Indigenous content and epistemologies through lenses of 'fear' and 'anxiety' and how the educators' anxieties stop their learning outside of settler colonial epistemology because of structures that impose fear to go outside of this epistemology. We examine how teachers can pause within these structures of 'fear' and explain strategies (Ascencio \& ChE, 2016) they can use to overcome the settler colonial epistemology in order to become imperfect accomplices. 


\section{Theoretical Framework}

In order to understand systemic barriers and discourses, we draw on the work of post-structural theorists (Britzman, 2000; Mills, 2003; Weedon, 1987). Discourses are "regulated by a set of rules which lead to the distribution and circulation of certain utterances and statements" (Mills, 2003, p. 54). In short, dominant discourses reproduce ideas of what is 'normal' and create hierarchies to ensure those in power remain in power through structures such as government, schools, housing, and so on. Discourses are simply "ways of constituting knowledge, together with the social practices" (Weedon, 1987, p. 108). They allow us to (not) say certain things, which reproduce power hierarchies with those who "consent [or] dissent" (Britzman, 2000, p. 36). We label the dominant discourse that circulates and has been/continues to be a barrier for the teaching of Indigenous epistemologies as "white settler colonial' because of the specific histories in the context of the research. In the region of Turtle Island where we conducted this research, white British and French settlers have developed power hierarchies through histories, law, and practices that benefit those white, male, heterosexual settlers who hold many positions of power in the Canadian context (Driskill, Finley, Gilley, \& Morgensen, 2011). This normative discourse of Canadian social and national settlement is embedded deeply in the national consciousness and in school curricula, as explained by Carroll (2018). This specific white settler colonial discourse reproduces what it views as 'normal' through these discourses including race, gender, sexuality, religion, ability, and so on. White settler colonial discourse and its boundaries are not natural or permanent, and we follow Jackson (2001) who explains, "that structures are not absolute and we become responsible for examining those structures and exposing what they do" (p. 396).

Walter Mignolo $(1995,2011)$ describes how analyzing the colonial matrix of power can serve as a guide in understanding coloniality, through authority, economy, knowledge and subjectivity, alongside race, gender, and sexuality, with religion and patriarchy at its centre. Mignolo (2011) explains that in order to work towards decolonization, people must invest in decoloniality, which involves an understanding that undermines the logic behind coloniality and modernity, as well as an "epistemic disobedience and delinking from the colonial matrix in order to open up decolonial options" (p. 9). Utilizing Mignolo's (2011) colonial matrix of power, we trace the establishment of white settler colonial discourse as being reproduced through theology/secular philosophy and patriarchy in curriculum and enacted by teachers. It is through Mignolo's (2011) theory that we understand opportunities to 'delink' from the white settler colonial discourse in the classroom, through "engaging in epistemic disobedience" (p. 9) and through the process of becoming "imperfect accomplices" (Carroll, 2019). This 'delinking' process, or ways in which one delinks/refuses these types of knowledge systems (authority, economy, knowledge and subjectivity, and race, gender, and sexuality), is part of a lifelong journey of self-reflection and education.

White settler colonial discourses create barriers for teachers who are teaching outside of settler colonial discourse or western epistemologies (Mignolo, 2011). These barriers are both explicit and implicit, and they are sometimes created through the discouragement of losing power in the classroom (Mignolo, 2011). In order to explain how these delinking processes can aid teachers in refusing white settler colonial discourses in their teaching, we must first understand the ways in which educators are speaking about their hesitancies in doing so through their lens of fear. With Ascencio and ChE (2016), we theorize the difference between fear and anxiety, as fear is a biological reaction and anxiety is a real and complex emotional and physical response but is often different than fearing for one's life. We purposefully include this theory which is outside of academia to think through the grassroots efforts required in this work.

Ascencio and ChE (2016) created a podcast we draw on, shortly after Donald J. Trump won the presidential election in the USA in December 2016. The purpose of the podcast was to think through the processes of feeling fear in uncertain times, in the era of Trump, and to move from a place of fear to a place of action. They explain fear as a biological reaction to an immediate threat to one's life or liberty (Ascencio \& $\mathrm{ChE}, 2016$ ). This biological reaction has been a useful tool throughout human history to alert us to something that needs to be noticed. In modern day times, this is relevant for many marginalized groups across Turtle Island that are targeted by police (Ascencio \& ChE, 2016). Although teachers are feeling uncomfortable with their lack of knowledge and skill on the subject of Indigenous epistemologies, we reframe their responses as discomfort and anxiety, instead of fear.

These ideas are similar to some psychiatry theories which explain the difference between fear and anxiety. For example, Sadock and Sadock (2007) explain that anxiety is based on an unknown, assumed threat. It is because of the thought of possible future experiences that one feels uncomfortable. However, fear is the response to a real, known, definite threat (Sadock \& Sadock, 2007). We expand these ideas to not only include the "suddenness of fear and the insidiousness of anxiety" (Sadock \& Sadock, 2007, p. 579), but to account for the real threat Indigenous and racialized peoples have about police- and state-sanctioned violence. These feelings of fear are real, and they are also 
prolonged and daily occurrences.

The educators in our study did have real feelings of discomfort and anxiety. Some examples of this are seen in how they did not want to offend others, feel embarrassment from teaching incorrect information, or be reprimanded by those in positions of power for teaching outside of the dominant discourse. We do not want to discount these feelings as untrue because they are real, difficult emotional responses to teaching in the current context. There are real consequences in teaching Indigenous content and epistemologies in the classroom when white settler colonial discourses are counter to these histories and ways of knowing. However, these feelings of discomfort do not have real, immediate consequences for the educator's life and freedom, which is how we conceptualize fear. As the educators think about the past and assumed future, they feel anxiety and discomfort based on the white settler colonial discourse that aims to keep the dominant discourse intact. We understand these feelings of anxiety and discomfort as real, but through this theory encourage educators to use these feelings to do three things in order to move past/through the feelings in order to turn the feelings into action. We draw on Ascencio \& ChE (2016) to explain three practical steps to move through the feelings by first pausing, then reflecting, and finally moving towards the feelings of discomfort. In the last section of this paper, we will show what this looks like in practice.

Part of putting this into practice is a process of what we describe as becoming imperfect accomplices, which builds on Susan Dion's (2007) work on educators' tendencies to claim a positionality of perfect strangers. The theory of imperfect accomplice was developed through Dion's (2007) work in Carroll's (2019) dissertation work, which encourages educators to refuse the identity of perfect stranger. Being a perfect stranger allows teachers to claim a positionality of 'not knowing' about these issues, and so not teaching them. Teachers claim that they do not know anything or that they know very little about Indigenous peoples and "there is an ease with which teachers claim this position" (Dion, 2007, p. 330). This positionality is not an apolitical position, and "is informed simultaneously by what teachers know, what they do not know, and what they refuse to know" (Dion, 2007, p. 331). Although teachers claim they do not know enough, the "Indians" we picture in our minds are based on "dominant discourses presented in school curriculum" (Dion, 2007, p. 330). In Dion's (2007) article, it is explained that educators turn away from including Indigenous ways of knowing for "fear of offending" (p. 331) because of this perceived lack of knowing, which we saw mirrored in our data.

As explained by Dion (2007), and seen clearly in our research:

[Educators] do know that ways of teaching that reproduce stereotypical representations are inadequate, thus there is a fear and a silence involved in addressing this content. The fear of offending, the fear of introducing controversial subject material, the fear of introducing content that challenges students' understanding of the dominant stories of Canadian history all support the claim for the position of perfect stranger (p. 331).

This positionality of not knowing enough — so not having the capabilities to teach the content—is based on these anxieties. Although the teachers in our study also tended to position themselves as perfect strangers to Indigenous ways of knowing, we too found a range of experiences that show a variety of ways teachers are navigating the white settler colonial curriculum in disruptive ways, explained in the last section of the paper.

We build this theory of perfect stranger with our understanding of imperfect accomplices. In order to understand the word accomplice, we draw on Indigenous Action Media (2014) who explain, an accomplice is "a person who helps another commit a crime" (p. 2) and are complicit together in actions against structural oppression. This is different from an ally, who may provide support, but it is often temporary. Accomplices "leverage resources and material support and... strategize with, not for" (Indigenous Action Media, 2014, p. 5) and continue to negotiate their relationship with Indigenous peoples to work against the settler colonial state. This means, instead of turning away from difficult conversations because of anxieties or discomfort with 'not knowing,' accomplices turn towards these difficult conversations. With an awareness of what one does and does not know, educators can uncover the dominant discourses that are embedded in their understandings of the curriculum and Indigenous ways of knowing. As settler educators, we cannot do this in imperfect ways, and we cannot be free from the white settler colonial discourse that the current education system and curriculum was built with/in. However, to not turn towards these conversations means that dominant discourses will continue to remain, and false information will continue to be taught. As settlers, it is our responsibility to educate ourselves and strive to do our best on these stolen lands, with the recognition that our relationships are bound by the Dish With One Spoon treaty agreement.

\section{Methodology}

Our methodology is guided through action research (Somekh, 2008) and narrative inquiry approaches (Clandinin, 
2006), which aim to understand relationships between participants and researchers (Clandinin \& Caine, 2008) and allowed participants to share their experiences through story telling (Chase, 2013). Using these frameworks enabled us to honour the participants' narratives, build horizontal learning communities, and helped us understand how educators were (not) incorporating Indigenous content and epistemologies into their teaching practices. Through this methodology and research project, we did not aim to seek representability or generalizability, but provided a space for understanding and giving back to the community through learning and networking opportunities for growth. Before collecting the data, we understood from previous research that teachers had discomfort including these topics in their classrooms, so creating a professional development conference which allowed these conversations for self-reflection and tools to help practictioners overcome their anxieties was central to our project.

The data from this project were collected from this one-day professional development conference with morning research sessions in April 2017. The conference was organized to share knowledge and practices of teaching Indigenous content and epistemologies with variously situated educators. More than 130 Indigenous and non-Indigenous in-service and pre-service teachers, administrators, and graduate students in education shared stories and gained understandings of how educators can bring Indigenous ways of knowing into their classrooms. The conference included a keynote, four optional research sessions where the data was collected, and two afternoon sessions of concurrent workshops in a variety of content areas (i.e., math, literacy, the arts, etc.) and topics (i.e., resistance, community organizations, etc.). The goal of the conference was to have deep conversations and learnings around these issues, as well as to gain an understanding of the barriers and successes educators had in their classrooms when teaching Indigenous content and epistemologies.

The morning research sessions were guided by our research questions: 1) how do teachers incorporate Indigenous content and epistemologies into their teaching practices, 2) what successes have they had in this area, and 3) what are the barriers they have faced? The four sessions included: a guided writing session; a talking circle; a collaborative visual art relational mapping session through collage; and a dramatic storytelling session. In each of the sessions, participants were asked questions through different methods guided by the research questions explained above. In the guided writing session, participants were asked questions and responded through writing, and in the talking circle it was similar but through speaking in a traditional talking circle. In the dramatic storytelling and visual art sessions, participants were asked in a variety of ways to reflect on their experiences through these creative forms. We chose to create four different ways to share stories with the researchers in order to build on the strengths and interests of the participants and their ways of sharing stories in productive ways (Chase, 2013). We chose a narrative approach of sharing experiences, as we feel that storytelling can be a powerful methodology which acts as healing and pedagogy (Coulter, Michael, \& Poynor, 2007). The research sessions were transcribed and coded using an emergent coding process (Saldaña, 2016) with multiple researchers' lenses, which highlighted major themes and significant concepts, guided through our theoretical framework explained above. In the four research sessions where data was collected, many significant themes arose and in this article, we highlight the ways in which the educators hesitated, stopped, and paused in their teaching of Indigenous content and epistemologies.

\section{Results}

It was evident through the data analysis that many of the non-Indigenous participants had anxieties teaching Indigenous content and epistemologies. These anxieties were enacted in two ways: stopping or avoiding the teaching of Indigenous content and epistemologies, or a productive pausing for self-reflection in order to find effective ways to move beyond settler colonial discourse. Although many of the participants classified their anxieties as 'fears,' as explained in the theoretical framework above, we mobilize the language of discomfort and anxieties to describe their stopping or pausing.

\subsection{Stopping and Avoiding the Teaching of Indigenous Content and Epistemologies}

Initially coming out of the data as 'barriers,' we found many anxious feelings emerge from the data which resulted in the stopping of teaching Indigenous content and epistemologies. We categorized the feelings that led to this action into three areas: rocking the boat, appropriation, and stereotyping. Through these conversations, discourses of reprimand, embarrassment, or rejection were prevalent; however, we see these reasons for stopping the teaching of Indigenous content and epistemologies as due to and reproducing white settler colonial discourse. It furthers the positionality of the educator as a 'perfect stranger,' instead of turning towards the discomfort in order to become imperfect accomplices.

Rocking the boat represented how educators were hesitant to do the work of incorporating Indigenous content and 
epistemologies into their classrooms because of the worry of offending others. Many educators had concerns about conflict or disagreement with Indigenous peoples, settler colleagues, school administrators, and even students. For example, one pre-service teacher participant explained, "The teacher candidate must feel comfortable teaching Indigenous epistemologies without fear that the associate teacher will frown upon that choice." This teacher-candidate assumes that the settler teacher, in a position of authority may reprimand them and refuse to acknowledge the importance of this work. Because of the white settler colonial structures, these thoughts are embedded in the teacher candidate's thoughts before the associate teacher says anything at all. In the words of another participant, they have been held back by the continued responses of their colleagues regarding incorporating Indigenous content: "I have too many encounters with educators in schools who hold views about Indigenous communities in Canada that seems to make them actively resist using an approach to teach Canada's history that respects Indigenous culture and accepts responsibility for the conditions Indigenous peoples live in today." This white settler colonial discourse reinscribes power hierarchies that place the white settler colonial curriculum as the 'truth' and Indigenous content as dissenting from the norm (Britzman, 2000). By including Indigenous content and epistemologies into the classroom, pre-service teachers are uncomfortable because they are committing "epistemic disobedience" (Mignolo, 2011, p. 9).

Another educator in the study explained, "this seems like a daunting task that makes many of us who are non-Indigenous uncomfortable because we don't know what to do and we don't want to get it wrong." The educator here is overwhelmed and is stopped in their tracks because of their feelings of discomfort and anxieties of being wrong. They are also absolving themselves of doing this work and contributing to the ever-present perfect stranger positionality. By expressing the need to feel 'comfortable,' settler teachers are enacting moves to innocence (Tuck \& Yang, 2012) through this perfect stranger positionality, and furthering white settler colonial curriculum. This frames teaching real histories as an 'option' which furthers the Othering of Indigenous bodies and histories (Said, 1979). It reproduces white settler colonial discourse and keeps the settler teacher's position in the power hierarchy intact.

This is not to discount these feelings as incorrect or untrue. Of course, we do not want teachers to be teaching incorrect information. There are real consequences to teaching incorrect information for both the educator and the students. There is also a 'call out' culture that exists, where people are confronted based on an individual often oppressive action/statement they have made. This can create toxic, defensive, and oppressive spaces, which are counter to the equitable and anti-oppressive spaces they aim to create (Loan Trần, 2013). We encourage educators to model 'calling in' in their environments, which calls into attention the white settler colonial discourse that allowed the action/statement to be said instead of attacking an individual action. Calling in is based on compassion and patience, with the end goal of education being key (Loan Trần, 2013).

Avoiding appropriation was the second form of anxiety or discomfort we found stopped the teaching of Indigenous content and epistemologies. The participants were concerned they would misrepresent or share knowledge in a way that is not acceptable. This stopping due to anxieties of making mistakes allows settler teachers to remain 'innocent' and further entrenches settler colonial epistemology. One participant explained, "I really do not have extensive experience about Indigenous knowledges or peoples and so there is a fear in not teaching it 'right' or capturing the true essence." However, for settler teachers, it is never possible to capture a "true" essence, nor can we become experts in frameworks or epistemologies that are not our own. Teaching these knowledges that are not our own will be appropriation in many ways. This is an incommensurable part of the work, but it cannot stop the teaching of Indigenous content and epistemologies. Instead, we must learn from our mistakes and commit to becoming better accomplices in order to work beyond the white settler colonial curriculum and delink from coloniality (Mignolo, 2011).

Discomfort in appropriating Indigenous cultures and traditions is a real emotion and concern that we need to grapple with. A participant explained "feeling uncomfortable, as a non-Indigenous person, that I am not going to teach the information properly or appropriately and that I'm going to tokenize people which will make things worse." Another participant shared that the barriers are not external, but internal: "I think the barriers I face/hold for teaching Indigenous education are internal. In recognizing my positionality as a non-Indigenous person, I feel intimidated when bringing an Indigenous perspective into the classroom. I am worried my own lack of knowledge would come through as inaccurate or appropriated teachings." Although explained as internal, these feelings of intimidation are based on discourses that have restricted access to true histories and non-colonial ways of being since the establishment of the education system on stolen land. However, these concerns of avoiding appropriation can cause teachers to stop teaching Indigenous content and epistemologies because they are frozen in their anxiety of being accused of appropriation or being 'called out' explained earlier, resulting in an unwillingness to make mistakes and a positionality of a perceived, apolitical 'perfect stranger.' Stopping their teaching due to these anxieties reflects the 
worry about doing the wrong thing, rather than focusing on the possibilities and opportunities for self-reflective productive pauses or becoming an imperfect accomplice, which will be explained in the next section.

Stopping because educators did not want to reproduce stereotypes was the third way in which we saw these anxieties manifest. Several of the educators in the study were uncomfortable teaching Indigenous content and epistemologies because they felt they may reproduce known or unknown stereotypes of Indigenous communities. Explained by one participant, "Some of the barriers that some of us experience is [sic] that we're fearful of perpetuating stereotypes that we maybe don't even know are stereotypes. So we are a little bit reluctant to incorporate these things into our teaching." As explained by Mignolo (2011), we must understand the colonial discourses in order to delink from them. If we are uncomfortable teaching math, can we be 'reluctant' to incorporate these concepts into the classroom? Of course not. However, the white settler colonial discourse allows for some knowledges to be seen as truth and others to be seen as alternative or factually additive. This multicultural, additive, 'inclusive,' mentality continues the white settler colonial discourse, as the white settler colonial curriculum remains intact and other knowledges are seen as "epistemic disobedience" (Mignolo, 2011, p. 9). In order to delink from these colonial 'truths,' we must commit ourselves to running towards feelings of discomfort and becoming imperfect accomplices.

\section{Moving Forward to Becoming Imperfect Accomplices}

Although many teachers spoke of stopping, many others were eager to engage with these messy realities to "rebuild and replace knowledge that was lost and subjugated in the past" (Participant). Another participant explained, there is

this notion that there is still anxiety and I think we need to acknowledge that, we don't need to know everything, but there are still anxieties even when you feel you know stuff. The more you know, the more you know you don't know. And that creates sort of further anxiety as you get into it.

Teachers simultaneously recognized that despite their anxieties, they chose to reflect and pause not as inaction, but as an effective solution to learn more, sit in discomfort, and reflect prior to making critical pedagogical decisions which helps to deconstruct the "colonial matrix of power" (Mignolo, 2011) and contributes to our framing of becoming imperfect accomplices. After reflecting and learning more about difficult issues and histories, teachers move into action, as they find ways to teach with different Indigenous epistemologies and histories. For example, one participant explained that an Indigenous student helped the teacher grow, "She made me accountable. She made me reflect every day on how/what I would do to include her voice." As the teacher paused and reflected on how they could include the student's voice into their teaching, new knowledge was created, even if mistakes in the process were inevitable.

This process of pausing in productive ways can be seen as a shift away from being a 'perfect stranger,' as explained by Susan Dion (2007), to becoming an 'imperfect accomplice,' drawing on Carroll (2019). Instead of being the perfect stranger, as explained in the theoretical framework, becoming imperfect accomplices means to turn towards anticolonial action to uncover structural oppression. Instead of turning away from action because of the anxiety to rock the boat, appropriate, or reproduce stereotypes, teachers can turn towards their anxieties or feelings of discomfort to build on their knowledge of teaching Indigenous content and epistemologies. Being an accomplice means becoming complicit in actions that question and subvert structural oppression. It is a life-long endeavor that we encourage teachers to strive for, in order to build their relationships with people that are marginalized by the white settler colonial state. It is in this process of being imperfect accomplices that we see three steps as being necessary to create space for delinking from settler colonial epistemologies. We draw on Ascencio and ChE (2016) and Mignolo (2011) to share these steps where teachers' anxieties can be made into productive pauses to delink the settler colonial epistemology of fear.

\subsection{Three Steps of Becoming Imperfect Accomplices}

The first step is grounding yourself in the moment, which is the process of allowing the feelings to arise and breathing into the feelings to bring yourself into the present, as opposed to thinking about future anxieties. Explained by Ascencio and ChE (2016), this grounding one's self in the moment allows for an activation of the parasympathetic nervous system, as opposed to a stress-induced fight or flight mode. Allowing for space to calm ourselves is important in reflection and action, and we argue, allows for more compassion. We see this as a multi-step process in itself, where teachers should incorporate self-care practices into their routine, in order to reflect on their daily stresses and let go. Many teachers do not take care of themselves, as the white settler colonial capitalist school system tries to convince us that we cannot afford the time to take care of ourselves (Shahajahan, 2015). In this education system, the mind is privileged over the body-spirit (which includes emotions and psyche) (Ng, 2011). 
Anticolonial action that promotes self care means incorporating meditation, exercise, journaling, and other reflective, self-care practices into your routine that pay attention to your mind, body, and spirit. When your body, spirit, and mind are healthy, your students also benefit (Parizeau, Shillington, Hawkins, Sultana, Mountz, Mullings, \& Peake, 2016).

This pausing and reflecting on your self can also occur in the classroom with students. Bringing mindfulness or embodied, self-reflective practices into the classroom is one way of working against dominant discourses that promote factory-style learning $(\mathrm{Ng}, 2011)$. By stopping and thinking about the ways that our actions are impacting those living and non-living things around us, we can be models for our students to take care of themselves and their communities. Roxana Ng (2011) explains,

Understanding the dissonance between body, mind, and spirit leads me to see that, regardless of whether we are the oppressor or the oppressed, the perpetrator or victim, we reproduce oppression through normalized patterns of behavior that have developed over time and have become 'natural,' automatic, and unconscious actions and ways of being in the world. (p. 361)

It is through questioning our automatic behavior that we can stop cycles of pain, which can be rooted in anxiety or stress.

When teachers are able to reflect on their knowledge, behaviors, or habits in a more objective way or unattached (less ego-full way), change is possible ( $\mathrm{Ng}, 2011)$. This means looking into ourselves, our thought patterns, our behaviors, and our habits in a critical way without judgement or guilt ( $\mathrm{Ng}, 2011)$. Mindfulness practices "enable one to develop the capacity to be mindful of one's thought and action, so that one does not go about one's daily business thoughtlessly and automatically as a matter of habit" $(\mathrm{Ng}, 2011$, p. 354). Through this process, people come to understand how their actions affect others. This pausing and reflecting on our own actions which incorporates self-care practices "is a method of decolonizing - undoing - ways in which we have come to be in the world" (Ng, 2011, p. 355).

However, this pausing/self-reflection takes time, as described by one participant, "I should experience a teaching about four times before I adopt it for use... It takes time to reflect, digest, and retransmit knowledge authentically and respectfully." Reflecting on these realities is a productive first step, which allows us to be grounded in the moment and gives us time to digest and learn new knowledge. It is not possible to hurry these topics, especially if one aims to become an accomplice. In addition to pausing to ground yourself in your body to reduce anxiety, it is important to learn about the communities and histories in which you teach. Creating goals that are realistic in learning about the multiple Indigenous communities and the histories of Turtle Island takes time, but is important in becoming an imperfect accomplice.

One example of a resource educators can access is the Deepening Knowledge website (https://www.oise.utoronto.ca/deepeningknowledge/Teacher_Resources/index.html). This website shares Indigenous content, histories, knowledges, and strategies with educators, and includes lessons, units, field trip ideas, and other resources sorted by subject and grade level. In addition to this, many communities and university campuses will have Indigenous resource centers with many resources to continue this journey of learning. As teachers continue to develop their understanding of the social studies, math, science curriculums, they too should develop their understanding and knowledge of their communities and histories.

In the second step, Ascencio and ChE (2016) recommend focusing on your privilege. This means realizing what one does have and the power or tools we have to overcome our discomfort and/or anxiety. They explain this through the lens of working for/with people who are racialized and who are rightfully fearful in the era of Trump. It is through this conversation that we can return to the discussion of fear versus anxiety. Racialized and Indigenous bodies are targeted by the state through white settler colonial policies and practices. A recent example, seen in the Ontario Human Rights Commission report of the Toronto Police Service, showed that although Black people represent only 8.8 percent of the population in Toronto, they were 20 times more likely than white people to be shot and killed by police, and represent $70 \%$ of the deaths caused by police shootings (OHRC, 2018). This represents real fear of people within Black communities in Toronto. In another report which includes Indigenous peoples' experiences, the researchers explain that racial profiling is a common occurrence across Ontario for Indigenous peoples, Muslims, Arabs, West Asians, and Black people (OHRC, 2017). Racial profiling is rooted in colonialism and it is important to think about the ways in which racialized and Indigenous people are fearful of their lives and liberty because of these processes. This is the real fear of one's life and freedom.

The ways in which Indigenous and racialized people are targeted by police are rooted in white settler colonial 
discourse. Thobani (2007) explains the ways in which the government purposefully creates a discourse that Canadian society is benevolent and welcoming through multicultural policies. It is through multicultural policies that the white settler is seen as the original inhabitant of Canada and the "multiracial, multi-ethnic, liberal-democratic society" (Thobani, 2007, p. 144) was only promoted after white privilege was rooted in the government, education, and overall society. These inclusion practices are always done "on the nation's terms" (Thobani, 2007, p. 159), through the white settler colonial discourse. These discourses continue their goals of invisibilizing or assimilating Indigenous peoples, while hypervisibilizing the "cultural stranger" or racialized person (Thobani, 2007, p. 145).

It is important to understand that the privilege one holds as a white settler is different than the privilege one holds as a racialized settler. The class, gender, sexuality, religion, and other subjectivities of the settler will also implicate the ways in which the educator will experience privilege in the settler education system. Thinking about how one is situated within these complicated hierarchies of power is no easy feat, but it is necessary in order to become imperfect accomplices. In order to reflect on one's privilege, reading about these hierarchies is necessary. We recommend taking a look at articles written by Cannon (2012), Dua and Lawrence (2005), McIntosh (1988), Macoun (2016), and Snelgrove, Dhamoon, and Corntassel (2014). This process of self-reflection also includes thinking about the ways one is not only benefiting from, but invested in, settler colonialism. Unless one is working within Indigenous-led organizations that are by/for Indigenous peoples, one is working in a system that is benefitting from being on stolen land. If you rent or own property, you are benefitting from the privatization of stolen land. If you drive a car or take public transportation, you are benefiting from oil extraction processes on stolen land with stolen resources. This complicity is part of a never-ending list, but it is important to be aware of the many ways we are all differently situated and benefitting from these processes and resources. As explained by Cannon (2018), "non-Indigenous people must come to know, understand, and challenge their own investment and implication in colonial dominance and self-identification" (p. 166).

Through this process of focusing on one's privilege, we recommend educators look into the ways they are variously situated within settler power hierarchies and advantaged within the social structures, so they can bring these understandings to the classroom and collaborate with Indigenous communities in deep, meaningful ways. This is not about feeling guilty, or about feeling good about feeling bad (as though feeling bad is good enough or that you've completed the work) (Simon, 2012). When we are in fight/flight mode, or working through a stress-based or anxiety-based lens, we often have narrow vision and can only see the negative (Ascencio \& ChE, 2016). If we take time, we are able to see how we can use our privilege through a lens of abundance instead of deficit and a lot of options and possibilities arise (Ascencio \& ChE, 2016). Explained by Simon (2012), when we listen to other peoples' stories, such as former residential school students, which are painful and traumatic, we often categorize these people into a "narrative of victimhood and not of victimization" (p. 132). This not only fails to call into question the systemic, institutional policies and practices that allowed for these atrocities to happen, but it often allows for the "commodification of stories of suffering," which allow the non-Indigenous person to "end up feeling good about feeling bad" (Simon, 2012, p. 133).

In our research project, one participant explained, "I do recognize that my own discomfort can be used to propel me to new knowledge, and that I shouldn't use my discomfort as an excuse to exclude Indigenous perspectives." One does not have the ability to exclude math or science from their teaching method because they are not strong in the subject. As educators, we must learn much content that may not be our strength based on our past experiences in the education system. It is time to stop making excuses for not including Indigenous content and epistemologies into the classroom, as if it is an elective. We are not perfect strangers, as Dion (2017) explains. We have the ability to learn in order to not continue the cycles that try to invisibilize Indigenous peoples from the history and current day colonization of Canada. The option of whether or not to bring anticolonial perspectives into the classroom is not an option every educator or student has, as different bodies are produced through affective intensities and politics (Ahmed, 2004).

This self-reflection is a life-long process that will continue to change as we change through history and contexts. After developing a foundational knowledge about the hierarchies of power that continue to colonize and aim to invisibilize Indigenous peoples and culture, it is important to reflect on the ways one can use one's privilege and position as an educator to work with/for Indigenous peoples in their communities. Building relationships and learning with Indigenous knowledge holders is key in the next phase, but it cannot be stressed enough that if one is drawing on Indigenous knowledge holders and bringing their expertise into the classroom, they should be compensated fairly for their input.

In the last step, we draw on Ascencio and ChE (2016) to encourage educators to run towards their anxieties 
and feelings of discomfort. Stopping to ground one's self allows for space to reflect on the privilege one holds, which can create the space and ability to run towards these feelings of discomfort. Moving from giving space to reflect and learn is important, but action is the ultimate goal. To overcome the 'fear,' teachers feel they have, they should focus on what they can do in their classrooms. Each small activity, resource, or conversation is important and needed in a colonial education system. Explained by Ascencio and ChE (2016), it is in this space that we can imagine a world where we did not follow colonialism and white settler colonial discourse.

Although many educators felt uneasy about including Indigenous content and epistemologies into their classrooms, many others were eager to collaborate with other educators, administrators, and Indigenous peoples to include these perspectives in their classrooms. Explained by one participant, "to collaborate in order to keep growing and reflecting on what you're learning... it's really about putting your students at the centre." In order to include perspectives into the classroom, we would encourage educators to also collaborate with others to ensure multiple perspectives are taken into account. Creating space for both collaborative and individual reflection in conversation with traditional knowledge holders is important in becoming an imperfect accomplice. As explained previously, properly compensating Indigenous communities for their input is very important in this process for ethical reasons, as well as for building relationships.

In order to overcome discomfort, we must move through the feelings and come to the other side, realizing that it was possible. This is not to say that mistakes will not happen. However, as imperfect accomplices, the alternative is not doing this work and we feel this is no longer an option. Although we will all make mistakes, only real learning and change can happen through these mistakes. With careful pausing, self-reflecting, and educating ourselves of the real histories of the place and ways in which we are all differently implicated in settler colonial processes, we believe anxieties can become a productive process of delinking from settler colonial curriculum.

\section{Conclusions}

Moving from anxiety and feelings of discomfort to action is necessary for educators in all settler colonial contexts to move beyond settler colonial discourse and structures that marginalize Indigenous peoples, content, and epistemologies. Although we can never be 'perfect' as settlers, we can aim to be imperfect accomplices - always striving to work with and for Indigenous peoples on their lands. Working together against these white settler colonial discourses that create barriers in doing this work is necessary to delink from coloniality and imagine new ways outside of the dominant discourse. Through taking time to pause, reflect on one's own privileges, and utilizing strategies to overcome anxiety and discomfort, we feel that teachers can move beyond white settler colonial discourse to further the goals of decolonizing education as imperfect accomplices.

\section{Acknowledgements}

We would like to acknowledge the contribution of the SSHRC Insight Grant, which funded this research project.

\section{References}

Ahmed, S. (2004). The cultural politics of emotion. Edinburgh: Edinburgh University Press.

Ascencio, C. L., \& ChE. (2016, December 8). Spirit medicine (a BGD podcast): Moving from fear to action (ep. 4). Podcast retrieved from https://www.bgdblog.org/2016/12/spirit-medicine-moving-fear-action-ep-4/

Britzman, D. (2000). "The question of belief": Writing poststructural ethnography. In E. A. St. Pierre \& W. S. Pillow (Eds.), Working the ruins: Feminist poststructural theory and methods in education (pp. 27-40). New York: Routledge.

Cannon, M. J. (2012). Changing the subject in teacher education: Centering Indigenous, diasporic, and settler colonial relations. Cultural and Pedagogical Inquiry, 4(2), 21-37. https://doi.org/10.18733/C3KS3D

Cannon, M. (2018). Teaching and learning reparative education in settler colonial and post-TRC Canada. Canadian Journal of Native Education, 40(1), 164-181.

Carroll, S. M. (2018). Uncovering white settler colonial discourse in curricula with anticolonial feminism. JCT: Journal of Curriculum Theorizing, 33(1), 22-40.

Carroll, S. M. (2019). Negotiating subjectivities through literature: Anticolonial counternarrative fiction book clubs 
and their possibilities. Dissertation. OISE at the University of Toronto. Retrieved from https://tspace.library.utoronto.ca/bitstream/1807/95767/1/Carroll_Shawna_M_201906_PhD_thesis.pdf

Chase, S. E. (2013). Narrative inquiry: Still a field in the making. In N. K. Denzin \& Y. S. Lincoln (Eds.), Collecting and interpreting qualitative materials (4th Ed.) (pp. 55-84). Los Angeles: Sage.

Clandinin, D. J. (Ed.). (2006). Handbook of narrative inquiry: Mapping a methodology. Thousand Oaks, CA: Sage. https://doi.org/10.4135/9781452226552

Clandinin, D., \& Caine, V. (2008). Narrative inquiry. In L. M. Given (Ed.), The SAGE encyclopedia of qualitative research methods (pp. 542-544). Thousand Oaks, CA: SAGE Publications Ltd. http://dx.doi.org/10.4135/9781412963909.n275

Coulter, C., Michael, C., \& Poynor, L. (2007). Storytelling as pedagogy: An unexpected outcome of narrative inquiry. Curriculum Inquiry, 37(2), 103-122. https://doi.org/10.1111/j.1467-873X.2007.00375.x

Dion, S. (2007). Disrupting molded images: Identities, responsibilities and relationships-teachers and indigenous subject material. Teaching Education, 18(4), 329-342. https://doi.org/10.1080/10476210701687625

Driskill, Q., Finley, C., Gilley, B. J., \& Morgensen, S. L. (2011). The revolution is for everyone: Imagining an emancipatory future through queer indigenous critical theories. In Q. Driskill, C. Finley, B. Gilley and S. Morgensen (Eds.), Queer indigenous studies: Critical interventions in theory, politics and literature (pp. 211-222). Tucson, AZ: University of Arizona Press.

Dua, E., \& Lawrence, B. (2005). Decolonizing antiracism. Social Justice, 32(4), 120-143.

Indigenous Action Media (2014). Accomplices not allies: Abolishing the ally industrial complex an Indigenous perspective. Retrieved from http://www.indigenousaction.org/wp-content/uploads/accomplices-not-allies-print-friendly.pdf

Jackson, A. Y. (2001). Multiple Annies: Feminist poststructural theory and the making of a teacher. Journal of Teacher Education, 52(5), 386-397. https://doi.org/10.1177/0022487101052005005

Loan Trần, N. (2013). Calling IN: A less disposable way of holding each other accountable. Retrieved from http://www.bgdblog.org/2013/12/calling-less-disposable-way-holding-accountable/

Macoun, A. (2016). Colonising white innocence: Complicity and critical encounters. In S. Maddison, T. Clark, \& R. de Costa (Eds.), The limits of settler colonial reconciliation: Non-Indigenous people and the responsibility to engage (pp. 85-102). Singapore: Springer. https://doi.org/10.1007/978-981-10-2654-6_6

McIntosh, P. (1988). White privilege and male privilege: A personal account of coming to see correspondences through work in women's studies. Wellesley, MA: Wellesley College, Center for Research on Women. Retreived from https://www.collegeart.org/pdf/diversity/white-privilege-and-male-privilege.pdf

Mignolo, W. (1995). The darker side of the Renaissance: Literacy, territoriality, and colonization. Ann Arbor: University of Michigan Press.

Mignolo, W. D. (2011). Introduction. In The darker side of western modernity: Global futures, decolonial options (pp. 3-24). Durham \& London: Duke University Press. https://doi.org/10.1215/9780822394501-001

Mills, S. (2003). Michel Foucault. London \& New York: Routledge. https://doi.org/10.4324/9780203380437

Ng, R. (2011). Decolonizing teaching and learning through embodied learning: Toward an integrated approach. In R. Foshay (Ed.), Valences of interdisciplinarity: Theory, practice and pedagogy (pp. 343-365). Edmonton: AU Press.

Ontario Human Rights Commission. (2017, April). Under suspicion: Research and consultation report on racial profiling in Ontario [PDF Report]. Retrieved http://www.ohrc.on.ca/sites/default/files/Under\%20suspicion_research\%20and\%20consultation\%20report\%20o n\%20racial\%20profiling\%20in\%20Ontario_2017.pdf

Ontario Human Rights Commission. (2018, December 10). OHRC interim report on Toronto Police Service inquiry shows disturbing results. Retrieved from http://www.ohrc.on.ca/en/news_centre/ohrc-interim-report-toronto-police-service-inquiry-shows-disturbing-resu lts

Parizeau, K., Shillington, L., Hawkins, R., Sultana, F., Mountz, A., Mullings, B., \& Peake, L. (2016). Breaking the silence: A feminist call to action. The Canadian Geographer, 60(2), 192-204. 
Sadock, B. J., \& Sadock, V. A. (2007). Kaplan \& Sadock's synopsis of psychiatry: Behavioral sciences/clinical psychiatry (10th ed.). Philadelphia: Wolter Kluwer/Lippincott Williams \& Wilkins.

Said, E. W. (1979). Orientalism. New York: Vintage Books.

Saldaña, J. (2016). The coding manual for qualitative researchers. Los Angeles: Sage.

Shahjahan, R. A. (2015). Being 'lazy' and slowing down: Toward decolonizing time, our body, and pedagogy. Educational Philosophy and Theory, 47(5), 488-501. https://doi.org/10.1080/00131857.2014.880645

Simon, R. I. (2012). Towards a hopeful practice of worrying: The problematics of listening and the educative responsibilities of Canada's truth and reconciliation. In J. Henderson \& P. Wakeham (Eds.), Reconciling Canada: Critical perspectives on the culture of redress (pp. 129-142) Toronto: University of Toronto Press.

Snelgrove, C., Dhamoon, R. K., \& Corntassel, J. (2014). Unsettling settler colonialism: The discourse and politics of settlers, and solidarity with Indigenous nations. Decolonization: Indigeneity, Education \& Society, 3(2), 1-32.

Somekh, B. (2008). Action research. In L. M. Given (Ed.), The SAGE encyclopedia of qualitative research methods (pp. 5-7). Thousand Oaks, CA: SAGE Publications Ltd. https://dx.doi.org/10.4135/9781412963909.n4

Thobani, S. (2007). Multiculturalism and the liberalizing nation. In Exalted subjects: Studies in the making of race and nation in Canada (pp. 143-175). Toronto: University of Toronto Press.

Tuck, E., \& Yang, K. W. (2012). Decolonization is not a metaphor. Decolonization: Indigeneity, Education and Society, 1, 1-40.

Weedon, C. (1987). Feminist practice and poststructuralist theory. Cambridge: Blackwell. 